\title{
Smart Rainwater Storage Technologies for Increasing Farmer's Economy in Rainfed and Tribal areas of Chhattisgarh
}

\author{
Vinamarta Jain*, A.L. Rathore, Abhay Bisen and Krishnakant Rajak
}

SKS College of Agriculture and Research Station, Rajnandgaon, IGKV-441491(C.G.), India

*Corresponding author

\section{Keywords \\ Farm Pond, \\ Farming System, \\ Water harvesting, \\ Ground water \\ recharge and \\ Storage}

\section{Article Info}

Accepted:

14 December 2018

Available Online:

10 January 2019

\section{A B S T R A C T}

Water scarcity has many negative impacts on the environment, including lakes, rivers, wetlands, and other fresh water resources. Furthermore, water shortage makes flow management in the rehabilitation of village streams problematic. Owing to poor water resource management system and climate change India faces a persistent water shortage. Indian agriculture accounts for $90 \%$ water use due to fast track ground water depletion and poor irrigation systems. Water is a critical input into agriculture in nearly all its aspects having a determining effect on the eventual yield. Adequate availability of water is important for crop and animal husbandry as well. India accounts for about $17 \%$ of the world's population but only $4 \%$ of the world fresh water resources. Distribution of these water resources across the vast expanse of the country is also uneven. The water received is prone to runoff, seepage and percolation much faster than its uptake for crop growth. This causes potential water shortage for rainfed rice at various stages and discourages adoption of modern rice technology. Thus development of irrigation is only the solution to meet-out the food demand of ever growing population and alleviating poverty from rural area. Expansion of irrigation through major and medium irrigation systems is nearly blocked due to many reasons. Adopting minor irrigation systems has its own limitation of ultimate irrigation potential of the area. Rainwater collection in dugout small farm-pond and recycle the collected water for irrigation purposes during in-season water stresses and for establishment of post rainy season crops are found profitable approach for rainfed areas of eastern India. Large number water harvesting ponds have been created but potential benefits are not realized owing to inefficient use of harvested water. The water harvesting pond can be making effective by adoption of farming system approach along with fertigation technique. This paper reviews the current status of water availability in rainfed areas, its usage in agriculture, water smart technologies developed in agriculture and how farmer's is attempting to move towards sustainable economy.

\section{Introduction}

India receives the highest rainfall among countries comparable to its size. Its landmass has gorgeous and perennial rivers crisscrossing it - particularly through the northern part. But the other side of the story is this: one part or another of India has continued to experience drought conditions with an alarming regularity. The rivers have been drying up and getting polluted. The underground water tables are shrinking 
rapidly. If water management is not accorded the importance it deserves, the country can very much expect to find itself in troubled waters as the years roll by. Estimates of the Central Ground Water Board are that the reservoir of underground water will dry up entirely by 2025 in as many as fifteen States in India - if the present level of exploitation and misuse of underground water continues. By 2050, when more than 50 per cent of the Indian population is expected to shift to the cities, fresh drinking water is expected to get very scarce. A new category of refugees is expected to emerge around that time: the water migrants. Future wars, between or within nations will be fought on the issue of water. The annual inter-State feuds over water are becoming more and more common in India. Per capita water availability in the country which was 5,000 cubic metres earlier, has dropped to 2,200 cubic metres. This is against the world figure of 8,500 cubic metres. As a result, India is fast approaching a phase of stressed water availability conditions.

The term rainwater harvesting is being frequently used these days; however, the concept of water harvesting is not new for India. Water harvesting techniques had been evolved and developed centuries ago. Since ancient times, farmers have been using ponds for livestock water and for irrigation. Particularly in rainfed areas, ponds and tanks are made for harvesting rainwater for recycling to irrigate crops during water stress periods. Even in farms that already have irrigation water from canals or wells and tubewells, provision of farm ponds may serve as an additional source of water. The demand for water has increased tremendously in recent years, and ponds are one of the most reliable and economical sources of water. Ponds are now serving a variety of purposes, including water for livestock and for irrigation, fish production, field and orchard spraying, fire protection, energy conservation, wildlife habitat, recreation, erosion control, and landscape improvement (Rathore et al., 1996 and 2006).

\section{Water harvesting farm pond}

Water harvesting pond is a small tank or reservoir constructed on the farm for the purpose of storing rainwater essentially from surface runoff. The design and construction of water harvesting ponds require a thorough knowledge of the site conditions and requirements. Ideal components of the farm pond technology includes (1) creation of farm pond using about 10-15\% area of farm, such that enough catchment available to generate runoff from major runoff events to fill the pond and place excavated soil to build embankments, (2) growing high value legumes, pulse or vegetable crops in the upper catchment area and rice in lower portion of the field during rainy season, (3) growing suitable post-rainy season crops using water saved in the pond and (4) fish and duck rearing in the pond as optional activity( $\mathrm{Pal}$ et al., 1994). Farm ponds are economically attractive in terms of economic returns but also in terms of unaccounted benefits such as increased employment, reduced risk of crop production, increased value of land, prospects of enhanced profitability by growing high value vegetables and fish culture. Furthermore, farm ponds can improve local hydrology (groundwater recharge, regulated stream flow and surface storage), reduce soil erosion, siltation and pollution of water bodies.

\section{Farm pond water balance}

Six farm ponds were constructed in each farming system models with view, to collect runoff and it's recycling for crop production during water stress periods in rainy season and for establishment of crops during post 
rainy season. Area of models was $0.40,0.80$ and 1.0 ha with and without shallow dug well. Inflow and outflow are the regular features of pond during rainy season (Rathore et al., 2001). Therefore, collected rainwater was 1.6-3.6 times to the capacity of ponds. The inflow and outflow characteristics are described below.

\section{Inflow}

Direct rainfall and runoff from catchment are the components of inflow. No significant interflow was observed during the growing period. In different ponds $35-47 \%$ runoff was collected and 3-6\% diverted as overflow from ponds to rice grown below. Of the total collected rainwater in pond, $77-82 \%$ received from runoff and remaining as direct rainfall into pond (Machiwal et al., 2004).

\section{Outflow}

Data of open pan evaporation was collected from meteorological laboratory located within $1 \mathrm{~km}$ distance from experimental site for calculation of evaporation from the ponds. As reported by several workers, $70 \%$ value of pan evaporation was taken for estimation of evaporation from the ponds.

Of the total outflows, 4-10\% collected water was lost as evaporation from different farm ponds depending on water storage duration and values of pan evaporation. Although measures are available to minimize the evaporation losses from water bodies but they are not cost effective vis-à-vis the losses are quite lower than other losses (Rathore et al., 20015).

\section{Seepage and percolation}

It was accounted to $42-52 \%$ of total outflow from the different ponds. On an average the S\&P losses were 14 to $39 \mathrm{~mm} /$ day in different ponds (Table 1). These losses were quite high therefore polythene lining is needed in the farm ponds. Minimizing these losses certainly enhanced water availability for crop production and other enterprises.

\section{Irrigation}

In different ponds $42-49 \%$ water was used for irrigation to different crops in various models.

\section{Farm water balance}

In field water balance; rainfall, supplemental irrigation, overflow from catchment, runoff/drainage and plant available soil moisture (PASM) are the measured factors. Based on these factors evapo-transpiration and percolation $(\mathrm{Et}+\mathrm{P})$ of the crops was computed. Rainfall (64-66\%) and runoff (15$17 \%)$ were the major source of farm water whereas supplemental irrigation accounted to $8-9 \%$ of total water gained in the farm (Table 2).

Evapo-transpiration + percolation were recorded as major use of farm water $(52-55 \%)$ whereas loss of $17-20 \%$ recorded drainage of water from upland and rice field area. Nearly $10 \%$ of farm water remained un-utilized as plant available soil moisture(PASM) after rabi crop (Table 3).

\section{Traditional use of farm ponds}

Large number of farm ponds is constructed in MNREGA but farmers rarely using the collected water efficiently in crop production. Farmer use to irrigate water in rice at a once or twice in a season wherever shortage of water occurred during the season.

If water remained in the pond after rice, that naturally percolate down in the pond without growing rabicrop. Thus farm ponds are not much attractive to farmers as source of assured water (Chary and Subbarao, 2003). 
Table.1 Characteristics of catchment and farm ponds (FP) constructed under farming system models (mean over 2005-06 to 2007-08)

\begin{tabular}{|c|c|c|c|c|c|c|}
\hline Characteristics & FP-1 & FP-2 & FP-3 & FP-4 & FP-5 & FP-6 \\
\hline Catchment area (ha) & 0.27 & 0.27 & 0.56 & 0.57 & 0.62 & 0.77 \\
\hline Rainfall (mm) & 1272 & 1272 & 1272 & 1272 & 1272 & 1272 \\
\hline Runoff $(\%)$ & 45.5 & 46.6 & 34.9 & 43.8 & 37.5 & 36.4 \\
\hline Capacity $\left(\mathbf{m}^{3}\right)$ & 655.7 & 779.0 & 1114.0 & 1407.7 & 1729.7 & 1723.3 \\
\hline Capacity inflow ratio & 2.5 & 2.3 & 2.4 & 2.4 & 2.3 & 2.3 \\
\hline Depth (cm) & 222.0 & 232.7 & 211.7 & 222.7 & 219.3 & 230.7 \\
\hline Seepage \& percolation $(\mathrm{cm} / \mathrm{day})$ & 2.9 & 2.2 & 2.5 & 2.1 & 1.4 & 2.0 \\
\hline Water availability period (days) & 116 & 118 & 117 & 129 & 158 & 148 \\
\hline
\end{tabular}

Table.2 Inflow and outflow characteristics of farm ponds under farming system models

\begin{tabular}{|c|c|c|c|c|c|c|c|c|c|c|c|c|}
\hline \multirow{3}{*}{$\begin{array}{l}\text { Inflow/ } \\
\text { outflow }\end{array}$} & \multicolumn{12}{|c|}{ Water balance of farm ponds } \\
\hline & \multicolumn{2}{|c|}{ FP-1 } & \multicolumn{2}{|c|}{ FP-2 } & \multicolumn{2}{|c|}{ FP-3 } & \multicolumn{2}{|c|}{ FP-4 } & \multicolumn{2}{|c|}{ FP-5 } & \multicolumn{2}{|c|}{ FP-6 } \\
\hline & $\left(m^{-3}\right)$ & $(\%)$ & $\left(m^{-3}\right)$ & $(\%)$ & $\left(m^{-3}\right)$ & $(\%)$ & $\left(m^{-3}\right)$ & $(\%)$ & $\left(m^{-3}\right)$ & $(\%)$ & $\left(\mathrm{m}^{-3}\right)$ & $(\%)$ \\
\hline \multicolumn{13}{|l|}{ Inflow } \\
\hline Runoff & 1195 & 83.1 & 1327 & 82.6 & 1841 & 79.5 & 1983 & 79.1 & 2684 & 78.6 & 2637 & 77.2 \\
\hline $\begin{array}{l}\text { Direct } \\
\text { rainfall }\end{array}$ & 251 & 16.9 & 287 & 17.4 & 482 & 20.5 & 526 & 20.9 & 737 & 21.4 & 772 & 22.8 \\
\hline Total & 1447 & 100 & 1614 & 100 & 2323 & 100 & 2509 & 100 & 3420 & 100 & 3409 & 100 \\
\hline \multicolumn{13}{|l|}{ Outflow } \\
\hline Irrigation & 648 & 44.9 & 696 & 42.8 & 1021 & 44.3 & 1036 & 42.1 & 1499 & 44.0 & 1642 & 49.1 \\
\hline $\begin{array}{l}\text { Seepage \& } \\
\text { percolation }\end{array}$ & 728 & 50.2 & 832 & 51.9 & 1164 & 49.7 & 1316 & 51.4 & 1735 & 49.1 & 1492 & 42.3 \\
\hline Evaporation & 70 & 4.9 & 85 & 5.4 & 139 & 6.0 & 158 & 6.4 & 237 & 7.0 & 275 & 8.5 \\
\hline Total & 1447 & 100 & 1614 & 100 & 2323 & 100 & 2509 & 100 & 3471 & 100 & 3409 & 100 \\
\hline Overflow & 176 & 5.6 & 163 & 2.5 & 386 & 5.7 & 361 & 5.5 & 516 & 5.8 & 502 & 5.9 \\
\hline
\end{tabular}


Table.3 Farm water balance of farming systems with farm pond and shallow dug well

\begin{tabular}{|c|c|c|c|c|c|c|}
\hline \multirow{2}{*}{$\begin{array}{l}\text { Components } \\
\text { Water gained }\end{array}$} & \multicolumn{2}{|c|}{0.40 ha IFS } & \multicolumn{2}{|c|}{0.80 ha IFS } & \multicolumn{2}{|c|}{ 1.0 ha IFS } \\
\hline & $\left(\mathrm{m}^{3}\right)$ & $(\%)$ & $\left(\mathrm{m}^{3}\right)$ & $(\%)$ & $\left(\mathrm{m}^{3}\right)$ & $(\%)$ \\
\hline Rainfall in cropped area & 5356 & 63.9 & 9669 & 65.7 & 12956 & 64.2 \\
\hline Overflow from pond diverted to rice & 193 & 2.3 & 374 & 2.5 & 509 & 2.5 \\
\hline PASM after kharif crops & 482 & 5.8 & 1022 & 6.9 & 1600 & 7.9 \\
\hline Direct rainfall in pond & 285 & 3.4 & 504 & 3.4 & 730 & 3.6 \\
\hline Runoff from uplands collected in pond & 1243 & 14.8 & 1912 & 13.0 & 2542 & 12.6 \\
\hline Irrigation to crops from pond \& well & 784 & 9.3 & 1185 & 8.1 & 1790 & 8.9 \\
\hline Water for livestock, farm and family use & 40 & 0.5 & 47 & 0.3 & 49 & 0.2 \\
\hline Total & 8382 & 100 & 14712 & 100 & 20175 & 100 \\
\hline \multicolumn{7}{|l|}{ Water use/ loss } \\
\hline Evapo-transpiration + percolation & 4355 & 52.0 & 8120 & 55.2 & 11074 & 54.9 \\
\hline Drainage from upland crops and rice & 1704 & 20.3 & 2581 & 17.5 & 3467 & 17.2 \\
\hline PASM after rabi crops & 756 & 9.0 & 1548 & 10.5 & 2313 & 11.5 \\
\hline Seepage and percolation from pond & 725 & 8.6 & 1240 & 8.4 & 1539 & 7.6 \\
\hline Evaporation from pond & 80 & 0.9 & 149 & 1.0 & 243 & 1.2 \\
\hline Irrigation from pond to crops & 723 & 8.6 & 1029 & 7.0 & 1490 & 7.4 \\
\hline Water for livestock, farm and family use & 40 & 0.5 & 47 & 0.3 & 49 & 0.2 \\
\hline Total & 8382 & 100 & 14712 & 100 & 20174 & 100 \\
\hline
\end{tabular}

Table.4 Investment cost and area brought under irrigation by surface water harvesting and ground water structures

\begin{tabular}{|l|c|c|c|c|c|}
\hline Type of structures & $\begin{array}{c}\text { No. of } \\
\text { structure }\end{array}$ & $\begin{array}{c}\text { Cost of } \\
\text { structure } \\
\text { (Rs. In } \\
\text { lakh) }\end{array}$ & $\begin{array}{c}\text { Area } \\
\text { irrigated } \\
\text { (ha) }\end{array}$ & $\begin{array}{c}\text { Average cost of } \\
\text { structure } \\
\text { (Rs. In lakh) }\end{array}$ & $\begin{array}{c}\text { Cost of per ha } \\
\text { irrigation } \\
\text { (Rs. In lakh) }\end{array}$ \\
\hline $\begin{array}{l}\text { Surface water harvesting } \\
\text { structure(WHS) }\end{array}$ & 68 & 146.20 & 170.20 & 2.50 & 1.16 \\
\hline $\begin{array}{l}\text { Ground water structure } \\
\text { (GWS) }\end{array}$ & 583 & 874.50 & 682.30 & 1.17 & 0.78 \\
\hline
\end{tabular}


Table.5 Production, net return and employment from various enterprises in farming system model with farm ponds

\begin{tabular}{|c|c|c|c|c|c|c|c|c|c|c|c|c|}
\hline \multirow[t]{2}{*}{ Enterprise } & \multicolumn{3}{|c|}{$\begin{array}{l}\text { Area allotted to } \\
\text { each enterprise }\end{array}$} & \multicolumn{3}{|c|}{ Production (kg/ Lt.) } & \multicolumn{3}{|c|}{ Net return (Rs.) } & \multicolumn{3}{|c|}{$\begin{array}{l}\text { Employment } \\
\text { (man day) }\end{array}$} \\
\hline & $\begin{array}{c}0.40 \\
\text { ha } \\
\text { IFS }\end{array}$ & $\begin{array}{c}0.80 \\
\text { ha } \\
\text { IFS }\end{array}$ & $\begin{array}{l}1.0 \\
\text { ha } \\
\text { IFS }\end{array}$ & $\begin{array}{c}0.40 \\
\text { ha } \\
\text { IFS }\end{array}$ & $\begin{array}{c}0.80 \\
\text { ha IFS }\end{array}$ & $\begin{array}{l}1.0 \text { ha } \\
\text { IFS }\end{array}$ & $\begin{array}{c}0.40 \\
\text { ha IFS }\end{array}$ & $\begin{array}{c}0.80 \\
\text { ha IFS }\end{array}$ & $\begin{array}{l}1.0 \text { ha } \\
\text { IFS }\end{array}$ & $\begin{array}{c}0.40 \\
\text { ha } \\
\text { IFS }\end{array}$ & $\begin{array}{c}0.80 \\
\text { ha } \\
\text { IFS }\end{array}$ & $\begin{array}{c}1.0 \\
\text { ha } \\
\text { IFS }\end{array}$ \\
\hline \multicolumn{13}{|l|}{ Crops } \\
\hline Rice & 0.13 & 0.26 & 0.35 & 537 & 1105 & 1514 & 2277 & 4707 & 6490 & 22 & 43 & 56 \\
\hline Soybean & 0.05 & 0.10 & 0.16 & 76 & 172 & 270 & 606 & 1230 & 2059 & 7 & 7 & 23 \\
\hline Maize & 0.01 & 0.03 & 0.04 & 42 & 95 & 150 & 512 & 1210 & 1877 & 10 & 19 & 31 \\
\hline Mustard & 0.13 & 0.27 & 0.35 & 97 & 197 & 232 & 1033 & 1975 & 2059 & 16 & 31 & 38 \\
\hline Arhar & 0.02 & 0.02 & 0.04 & 24 & 31 & 61 & 331 & 394 & 798 & 3 & 5 & 4 \\
\hline Gram & 0.12 & 0.28 & 0.43 & 115 & 304 & 469 & 1642 & 4181 & 6371 & 16 & 33 & 50 \\
\hline Ladyfinger & 0.04 & 0.09 & 0.15 & 318 & 829 & 1330 & 972 & 1859 & 4316 & 12 & 30 & 71 \\
\hline Tomato & 0.02 & 0.02 & 0.02 & 186 & 268 & 289 & 625 & 1011 & 1188 & 6 & 9 & 8 \\
\hline Brinjal & 0.01 & 0.03 & 0.03 & 193 & 368 & 527 & 860 & 1736 & 2669 & 8 & 14 & 14 \\
\hline $\begin{array}{l}\text { Multi-cut } \\
\text { sorghum }\end{array}$ & 0.04 & 0.09 & 0.13 & 3770 & 7870 & 10142 & 1590 & 3227 & 6567 & 6 & 11 & 20 \\
\hline Marigold & 0.01 & 0.01 & 0.01 & 70 & 89 & 104 & 463 & 527 & 537 & 3 & 4 & 4 \\
\hline Drumstick & 0.05 & 0.13 & 0.16 & 10 & 20 & 27 & 42 & 193 & 334 & 9 & 20 & 14 \\
\hline Total crops & 0.63 & 1.33 & 1.87 & 5437 & 11347 & 15114 & 10952 & 22248 & 35262 & 117 & 224 & 331 \\
\hline \multicolumn{13}{|c|}{ Milk produced } \\
\hline Cow & 0.06 & 0.10 & 0.12 & 1619 & 3029 & 4468 & 11136 & 39346 & 30531 & 50 & 94 & 92 \\
\hline Goat & & & & 50 & 61 & 120 & 1250 & 1820 & 2405 & 4 & 0 & 14 \\
\hline \multicolumn{13}{|c|}{ Meat produced } \\
\hline Goat & & & & 302 & 408 & 689 & 5658 & 13199 & 21961 & 29 & 74 & 74 \\
\hline \multicolumn{2}{|l|}{ Poultry birds } & & & 10 & 13 & 22 & 550 & 930 & 1325 & 8 & 14 & 9 \\
\hline Fish & & & & 9 & 14 & 50 & 259 & 626 & 1477 & 5 & 11 & 11 \\
\hline Grand total & 0.69 & 1.43 & 1.99 & 7428 & 14873 & 20463 & 29804 & 78169 & 92961 & 213 & 417 & 530 \\
\hline $\begin{array}{l}\text { Traditional } \\
\text { rainfed rice }\end{array}$ & 0.40 & 0.80 & 1.00 & 760 & 1520 & 1900 & 2757 & 3995 & 4860 & 65 & 119 & 144 \\
\hline \multicolumn{13}{|c|}{$\begin{array}{l}0.40 \text { ha IFS: Rice + oilseed + pulse + vegetables + flower + fruit plants + green fodder + Farm pond+ dug } \\
\text { well+ Cow (1) + Goat(6) + Poultry birds(15) + Fish }\end{array}$} \\
\hline \multicolumn{13}{|c|}{$\begin{array}{l}\text { 0.80 ha IFS: Rice + oilseed + pulse + vegetables + flower +fruit plants + green fodder + Farm pond + dug well } \\
+\operatorname{Cow}(2)+\operatorname{Goat}(9)+\text { Poultry birds }(20)+\text { Fish }\end{array}$} \\
\hline 1.0 ha IFS: I & ice + & seed & pulse & veget & les + fl & er+ fru & plants & reen & ler + & & & \\
\hline
\end{tabular}


How to make farm ponds an economic and attractive water resource?

Surface water harvesting structures are the alternative where ground water availability is meager. But WHS are costlier than GWS and require more investment compare to GWS. Normally WHS is constructed in sloping area whereas GWS are constructed in lowlands. Thus it is required to make WHS economical and attractive to the farmers so that WHS become attractive in farm families (Table 4).

\section{Farm ponds with farming system approach}

Farm pond with dug well helped in bringing the area under double cropping. Crop diversification encouraged efficient use of water for crop production (Table 5). With availability of water crop yields were almost double in all the crops adopted in the integrated farming systems. Net income and employment opportunities were almost double in all the farming systems with pond and well. A farmer may get nearly one-lakh by adopting suggested farming system with farm pond and dug well. Animal component in the suggested farming system contributed $60-70 \%$ farm income whereas cropping share was $30-40 \%$. Therefore for livelihood security of small farmer, livestock rearing is important in addition to cropping.

\section{Surface water harvesting and trapping percolated ground water}

Rain runoff flows on surface can be harvested in farm ponds but part of it percolated down in soil profile and thereafter recharges ground water. Soil profile water can be tapped in dug well and tube well. The open dug wells should be located in the recharge zone of the tanks. For optimum efficiency, the well diameter should be $6 \mathrm{~m}$ and depth should be $8 \mathrm{~m}$. In lower reaches of the drainage line, shallow ditches can also serve the purpose, especially if sufficient command area is not available or farmers are poor to invest in open dug well. Multiple use of water should form an integral part of the utilization of the system. The water body can be used for pisci-culture and duck rearing, and embankment can be used for cultivation of fruit crops as well as vegetables. This will improve nutritional uptake of the farmers and provide round the year income and employment. In-situ conservation of excess rainfall in a systematic manner, involving on-farm reservoirs in series is most appropriate and economically viable technology as first line of defence against drought (Sharda et al., 2006).

\section{(c). Water harvesting ponds with farming system and micro irrigation}

Farm pond has great potential for supplemental irrigation but to make economical viable approach, it should be promoted with farming system approach and irrigation adopting drip system or sprinkler. Inclusion of well or tube well assure promising income to the farmer by growing round-the year fish and duck in pond in addition to growing vegetable and fruit plants to fetch income on sustainable basis (Singh et al., 2007).

In conclusions, farm ponds are being constructed on farmer's field and revenue or forest land for ground water recharge or alleviation of drought. But its potential benefits are not realized owing to non-integration of essential technologies.

This leads to least attraction and adoption of the farm ponds even after free digging of the ponds on farmer's field under MNREGA and other schemes. To make more remunerative and farmer adoptable technology following point should be integrated along with digging of pond as part of the scheme:

Farm pond after digging must be polyethylene lined.

Schemes should be linked for adoption of farming system approach and micro irrigation (drip or sprinkler irrigation) with construction of each pond.

Farm pond for surface water, dug well for soil profile water and tube well for ground water shall 
be constructed in integration for conjunctive use of water.

There should be a small pond for recharge and Pisci-culture near each tube well

\section{References}

Chary, K.R.R., Subbarao N.V. (2003). Design of artificial structures to improve ground water quality proceeding. International conference on hydrology and watershed management centre for water resources J. Nehru Tech. University, Hyderabad, India: 339-349.

Machiwal D., Jha M.K., Singh P.K., Mahnot S.C., Gupta A. (2004). Planning and Design of cost-effective water harvesting structures for efficient utilization of scarce water resources in semi-arid regions of Rajasthan India water Resource Management 18; 219235.

Pal,A.R., Rathore, A.L. and Pandey, V.K.(1994). Rainwater storage systems for improving riceland productivity: opportunities and challenges for eastern India. Pages 105-125 in On-farm reservoir systems for rainfed ricelands. S.I Bhuiyan, ed. IRRI, P.O. Box 933, Manila, Philippines.

Rathore A.L., KhareAbhishek, Rajput RS, Malaiya S and Sahu KK. (2006). Farming system models for increasing productivity, income and employment of resource poor small rainfed rice farmer of Chhattisgarh. National Symposium on Conservation and management of agro-resources in accelerating the food production for $21^{\text {st }}$ century. Organized by agronomy chapter, held at IGKV, Raipur from 1415, Dec. 2006.
Rathore, A.L., Sahu, K.K., Sharma, M.L., Rajput, R.S and Khare, A (2007). Integrated farming system for enhancing water productivity, income and employment opportunity of small rainfed rice farm "South Asian Conference on Water in Agriculture: Management options for increasing crop productivity per drop of water", 15-17 November 2007, IGKV, Raipur, Chhattisgarh, India.

Rathore, A.L., Pal, A.R., Sahu RK, Choudhari JL. (1996). On-farm rainwater and crop management for improving productivity of rainfed areas. Agricult. Water Management (Netherland). 31 (1996). 253-267.

Rathore, A.L., Pal, A.R. and Sahu K.K. (2001). Hydrological characteristics and economics of small farm ponds in rainfed rice areas. J. Agril. Issues 6(1): $1-14$.

Rathore, A.L., Jain, C.L., Patil, S.K., Sharma, R.L., BirbalSahu and Deepti, Jha. (2015). Scope and limitations of rice fallows for sustainable livelihood. Published by Indira Gandhi Krishi Vishwavidyalaya and state Agricultural management and extension training institute, Raipur (Chhattisgarh), p 148.

Sharda V.N. Kurothe R.S. Sena D.R. Pande V.C. Tiwari S.P. (2006). Estimation of ground water recharge from water storage structures in semi-arid climate of India. J. Hydrol., 329:224-243.

Singh J.B., Behari P., Yadava R.B. (2007). On the estimation of evapotranspiration water use efficiency and crop coefficient of lucerna (Medicago sativa L.) in central India Current science 93 (1) 17-19.

\section{How to cite this article:}

Vinamarta Jain, A.L. Rathore, Abhay Bisen and Krishnakant Rajak. 2019. Smart Rainwater Storage Technologies for Increasing Farmer's Economy in Rainfed and Tribal areas of Chhattisgarh. Int.J.Curr.Microbiol.App.Sci. 8(01): 2083-2090.

doi: https://doi.org/10.20546/ijcmas.2019.801.218 